\title{
PERANCANGAN SISTEM INFORMASI LOGISTIK DAN PERGUDANGAN DI YAYASAN DHARMA BHAKTI BERAU COAL
}

\author{
Fahriza Fawwas Asrory $\varpi^{1)}$ dan Dewi Safitriani $\oplus^{2)}$ \\ ${ }^{1,2}$ Teknologi Rekayasa Logistik, Politeknik Sinar Mas Berau Coal \\ ${ }^{1,2}$ Jl. Raja Alam 2 Kelurahan Sei Bedungun Kecamatan Tanjung Redeb, Kabupaten Berau, 77315 \\ E-mail : riza.asrory@polteksimasberau.ac.id ${ }^{1)}$, dewisafitriani@polteksimasberau.ac.id ${ }^{2)}$
}

\begin{abstract}
ABSTRAK
Yayasan Dharma Bhakti Berau Coal (YDBBC) menghadapi permasalahan pada sistem logistik mulai dari penanganan gabah dari petani kemudian masuk proses pengolahan sampai menjadi padi. Sistem input data yang dilakukan saat ini belum berjalan dengan baik. YDBBC masih menggunakan cara manual dalam proses administrasi pergudangan nya di mana penggunaan teknologi informasi masing sangat kurang. Kondisi ini cukup menyulitkan YDBBC dalam hal pengaksesan informasi administrasi pergudangan. Aliran informasi yang dilakukan secara manual ini menimbulkan dampak bagi yayasan seperti data tercecer, kesalahan dalam penginputan administrasi serta terhambat nya proses produksi. Melihat kondisi tersebut maka perlu perbaikan terhadap sistem logistik dan pergudangan yang sedang berjalan dan kemudian memberikan rancangan sistem infomasi logistik dan pergudangan kepada YDBBC untuk mempermudah proses pengelolaannya. Penelitian ini bertujuan untuk memberikan rancangan sistem informasi logistik dan pergudangan YDBBC agar proses penginputan data dapat mudah digunakan oleh user di gudang. Metode yang digunakan pada penelitian ini adalah metode System Development Life Cycle (SDLC). Dalam perencanaan System Development Life Cycle (SDLC) dimulai dengan menentukan dan mendefinisikan sistem informasi, selanjutnya data di analisis, kemudian di desain atau dirancang sesuai dengan sistem informasi yang ada. Hasil rancangan kemudian diimplementasikan, di uji dan hasilnya akan digunakan oleh user. Kelebihan dari hasil perancangan sistem logistik ini adalah mempermudah administrasi data dan pengelolaan data. Penerapan rancangan sistem informasi pergudangan dan logistik di gudang YDBBC terbukti dapat memudahkan karyawan dalam proses pengelolaan data gudang mulai dari beras masuk ke gudang, pengelolaan stok gudang, sampai pengelolaan data pemesan/konsumen beras dari gudang.
\end{abstract}

Kata Kunci: Yayasan Dharma Bhakti Berau Coal, Sistem Informasi, Sistem Logistik, Sistem Pergudangan, System Development Life Cycle (SDLC)

\section{PENDAHULUAN}

Yayasan Dharma Bhakti Berau Coal (YDBBC) adalah sebuah yayasan yang didirikan pada tanggal 6 Mei 2010 yang berlokasi di Kabupaten Berau. YDBBC memiliki tiga tugas utama dalam menjalankan programprogram CSR/PKM dari PT Berau Coal meliputi bidang pendidikan dan pelatihan, kesehatan dan nutrisi, serta pengembangan ekonomi, lingkungan, dan budaya.

Salah satu program CSR/PKM YDBBC adalah di bidang pengembangan ekonomi dimana YDBBC melakukan pemberdayaan kelompok tani tanaman padi di wilayah Kabupaten Berau. Adanya kegiatan ini diharapkan mampu meningkatkan kesejahteraan dan kualitas hidup para petani padi di Kabupaten Berau. Kegiatan yang dilakukan YDBBC meliputi pembinaan dan penyuluhan kepada kelompok petani padi, pemberian bibit padi kepada kelompok petani padi, dan pembelian beras hasil panen dari kelompok petani yang ada dibawah pembinaan YDBBC.

Permasalahan yang dihadapi oleh YDBBC adalah pada tahap penanganan pasca panen. Sistem logistik mulai dari penanganan gabah dari petani kemudian masuk proses pengolahan sampai menjadi padi dan dikirim ke gudang kemudian masuk ke proses sistem pergudangan nya belum berjalan dengan baik. Tujuan utama dari gudang adalah mengelola pergerakan dan penyimpanan barang secara efisien dengan mengoptimalkan penggunaan tempat yang ada dan mengetahui secara spesifik dimana barang akan disimpan setiap saat (Yanuar, dkk., 2021). Fungsi dari sistem logistik adalah untuk merencanakan, melaksanakan, dan mengendalikan keefektifan pencatatan permintaan, penerimaan, pengeluaran, pemakaian dan keefisienan dalam melihat stock barang dan aliran barang secara real time dan dapat terintegrasi dengan sistem yang lain (Setiawan and Setiyadi, 2017). Manajemen logistik merupakan aktivitas yang sangat penting dalam sebuah perusahaan atau perkantoran. Fungsi logistik tidak lagi dipandang sebagai pendukung dalam operasional perkantoran, namun sebagai salah satu fungsi yang akan meningkatkan efektivitas dan efisiensi instansi tersebut. Logistik berkaitan erat dengan pengaturan aliran barang atau jasa dari supplier, pabrikasi, sampai dengan ke konsumen. Keberhasilan logistik yang baik dapat dilakukan dengan menggunakan sistem informasi yang efektif dan efisien. Untuk menuju keberhasilan tersebut 
diperlukan sebuah perancangan sistem informasi yang baik dan benar (Wadisman, 2018).

YDBBC saat ini masih menggunakan cara manual dalam proses administrasi pergudangan nya dimana penggunaan teknologi informasi masing sangat kurang. Kondisi ini cukup menyulitkan YDBBC dalam hal pengaksesan informasi administrasi pergudangan. Aliran informasi yang dilakukan secara manual dapat menimbulkan dampak bagi yayasan seperti data tercecer, kesalahan dalam penginputan administrasi, serta keterlambatan dalam pencarian dan pencatatan. Dampak tersebut dapat mengakibatkan terhambat nya proses produksi.

Pembebanan tugas terhadap seorang yang melakukan sistem manual dapat menyebabkan kemungkinan kesalahan penulisan dan pengolahan data. Proses manual ini juga menyebabkan proses pembuatan laporan memakan waktu yang lama (Prasetyo, dkk., 2018). Tidak adanya sistem informasi pergudangan menyebabkan barang rusak dalam penyimpanan, rusak dalam handling, salah menyimpan barang, selisih stok dan lain-lain (Prasetyo, dkk., 2018). Dengan menggunakan sistem informasi manajemen logistik dapat dihasilkan laporan yang berisi informasi stok barang,, purchasing, forecasting kebutuhan tahun depan, report serta nilai barang dan aset sebagai acuan untuk membantu pimpinan/manager dalam menganalisis dan menindaklanjuti keputusan yang berkaitan dengan logistik perusahaan (Sukendar, 2018).

Melihat kondisi di atas maka perlu perbaikan terhadap sistem logistik dan pergudangan yang sedang berjalan dan kemudian memberikan rancangan sistem infomasi logistik dan pergudangan kepada YDBBC untuk mempermudah proses pengolahannya. Tujuan utama dari implementasi Teknologi Informasi (TI) di suatu organisasi atau perusahaan adalah untuk meningkatkan efektifitas proses, efisiensi waktu dan keunggulan bersaing suatu perusahaan (Setiawan dan Setiyadi, 2017).

Menurut Athoilah (dalam Prasetyo, dkk., 2018) sistem informasi pergudangan memberikan keuntungan antara lain mempercepat proses, mengetahui semua transaksi dan jumlah stok dengan lebih cepat dan akurat, mempermudah mengatur lokasi penyimpanan barang, dan lain-lain. Kemudian dalam penelitian Gasper (dalam Prasetyo, dkk., 2018) menjelaskan dengan adanya sistem informasi pergudangan akan mempermudah dan mempercepat pekerjaan pegawai. Pembangunan sistem informasi monitoring logistik dalam pengontrolan persediaan barang yang dapat memberikan kemudahan dalam mengelola data dan informasi bidang logistik, menyediakan data logistik yang akurat untuk keperluan perencanaan kebutuhan barang dan membantu dalam aliran informasi (Satyagraha dkk. 2020).

Sistem informasi sekarang ini mempunyai peran yang sangat signifikan dalam pengolahan data dengan adanya sistem informasi ini memudahkan manusia menjalankan pekerjaannya, diantaranya dapat menghemat waktu, ruang dan meminimalisasi biaya pengeluaran (Basar, dkk., 2021).

Melihat permasalahan tersebut maka diperlukan sebuah sistem yang mampu mengintegrasikan proses yang ada pada gudang YDBBC.

\section{RUANG LINGKUP}

Pengelolaan data gudang Yayasan Dharma Bhakti Berau Coal saat ini masih dilakukan secara manual. Hal ini sering menimbulkan masalah ketika puncak panen tiba. Ketika puncak panen stok beras yang masuk ke gudang cukup tinggi. Karena pengelolaan data masih dilakukan secara manual, seringkali menimbulkan permasalahan dalam pencarian dan pencatatan item, data yang tercecer, sehingga menyebabkan terhambat nya proses produksi. Perancangan sistem informasi logistik dan pergunakan dimaksudkan untuk mengatasi permasalahan tersebut. Rumusan masalah yang akan diselesaikan dalam penelitian ini adalah bagaimana penerapan sistem informasi logistik dan pergudangan pada gudang YDBBC.

Sistem informasi yang akan dibuat nanti mencakup stock in dan stok out beras di gudang. Stock in mengatur proses dan detail beras yang akan masuk ke gudang yang dalam hal ini pasokan beras dari petani, stock out mengatur proses dan detail beras yang akan keluar dari gudang yang dalam hal ini beras yang dibeli oleh konsumen/pemesan. Dengan adanya sistem informasi ini diharapkan akan mempermudah proses pengelolaan gudang mulai dari beras masuk dari petani, pengelolaan di dalam gudang, sampai dengan beras siap dikirim ke konsumen.

\section{BAHAN DAN METODE}

Pengembangan sistem informasi logistik dan pergudangan di Yayasan Dharma Bhakti Berau Coal (YDBBC) menggunakan metode System Development Life Cycle (SDLC) dengan penjelasan sebagai berikut:

1. Pengumpulan Data

Pada tahap ini dilakukan pengumpulan data dengan cara observasi langsung di lokasi gudang YDBBC dan daerah pemasok padi (petani padi) yayasan, wawancara dengan pengelola gudang yayasan dan beberapa petani padi pemasok gudang yayasan, permintaan data produksi dan penjualan gudang yayasan.

2. Identifikasi Masalah

Pada tahap ini masalah diidentifikasi dengan melakukan beberapa tindakan.

1) Mempelajari aliran bahan baku (beras dan gabah) mulai dari pemasok (petani padi) kemudian masuk ke gudang dan sampai ke pihak pemesan beras yayasan.

2) Mempelajari kondisi gudang yayasan dengan cara mempelajari ketentuan-ketentuan dan aturanaturan yang berlaku di yayasan dalam pengelolaan gudang yayasan. 
3) Menganalisis sistem produksi gudang yayasan dengan membuat simulasi sistem produksi berdasarkan data yang telah dikumpulkan pada tahapan sebelumnya.

3. Studi Literatur

Pada tahapan ini dilakukan dengan mempelajari buku-buku referensi atau sumber-sumber yang berkaitan dengan penelitian ini, baik dari text book, internet, maupun penelitian-penelitian terdahulu yang dapat mendukung penelitian ini.

4. Perancangan Sistem

Dalam perancangan sistem ini digunakan metode System Development Life Cycle (SDLC) atau biasa disebut siklus hidup pengembangan sistem.

1) Perencanaan Sistem

Tahapan perencanaan ini bertujuan untuk menentukan dan mendefinisikan sistem informasi seperti apa yang akan dikembangkan sehingga dapat membantu pihak yayasan dalam melakukan pengelolaan gudang. Pada tahap ini dikumpulkan beberapa perangkat lunak dan perangkat keras yang akan digunakan untuk membuat sistem informasi berbasis desktop.

2) Analisis Sistem

Pada tahap ini dilakukan analisis sistem pengelolaan gudang yayasan. Dari analisis ini nantinya akan dicari kekurangan sistem pengelolaan gudang yayasan. Setelah diketahui kekurangannya, langkah selanjutnya adalah memberikan usulan perbaikan sistem logistik dan pergudangan yang ada di yayasan. Usulan perbaikan ini berupa sistem pengelolaan gudang berupa aplikasi.

3) Rancangan Sistem

Tahapan perancangan sistem dibagi menjadi tiga bagian. Antarmuka di mana pada tahap ini akan dirancang susunan antarmuka dari sistem informasi logistik dan pergudangan yang dikembangkan, basis data di mana pada tahap ini akan dirancang sistem basis data dari sistem informasi logistik dan pergudangan yang dikembangkan dengan menggunakan SQL Server, dan basis model di mana pada bagian ini akan dirancang flowchart untuk model sistem informasi logistik dan pergudangan yang dikembangkan.

4) Implementasi Sistem

Tahap ini disebut sebagai tahap implementasi perangkat lunak atau coding. Dengan kata lain, pada tahap ini dilakukan implementasi hasil rancangan kedalam baris-baris kode program yang dapat dimengerti oleh mesin (komputer). Pada tahap implementasi ini menggunakan bahasa pemrograman C Sharp (C\#).

\section{Uji Coba}

Pada tahap ini dilakukan pengujian masing-masing fitur dan fungsi untuk mengetahui apakah aplikasi bekerja dengan semestinya. Jika aplikasi belum berjalan sesuai fungsinya maka dilakukan penganalisisan ulang terhadap sistem sehingga aplikasi dapat berjalan sesuai fungsinya.

6. Kesimpulan

Tahap akhir dari penelitian ini adalah menyimpulkan dari hasil yang diperoleh dari tahap-tahap sebelumnya.

Untuk mempermudah pembacaan langkah-langkah pengembangan sistem informasi di atas, dapat dilihat dalam bentuk diagram alir seperti Gambar 1 .

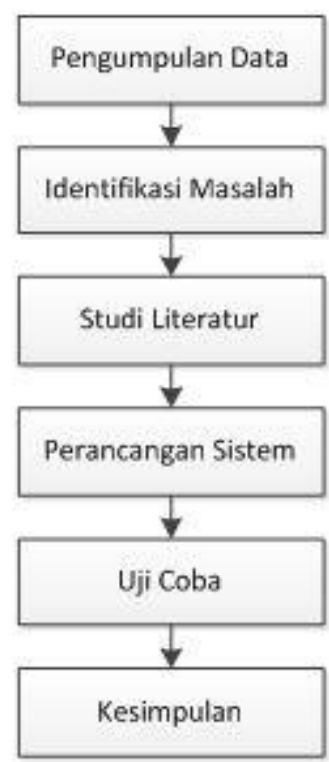

\section{Gambar 1. Tahapan Pengembangan Sistem Informasi Logistik dan Pergudangan}

\subsection{Sistem Informasi}

Sistem adalah gabungan dari berbagai elemen yang bekerja sama untuk mencapai suatu target atau tujuan (Heriyanto, 2018).

Sistem informasi dapat didefinisikan sebagai sekumpulan elemen atau komponen yang saling terkait yang mengumpulkan (memasukkan), memanipulasi (proses) dan menyebarkan (keluaran) data dan informasi dan memberikan mekanisme umpan balik untuk memenuhi tujuan organisasi (Ekawati and Wahyudiharto, 2021).

Sistem informasi berbasis komputer dalam suatu organisasi terdiri dari komponen-komponen berikut (Pujiiastuti, dkk., 2020):

1. Perangkat Keras

Komponen untuk melengkapi kegiatan memasukan data, memproses data, dan keluaran data.

2. Perangkat Lunak

Program dan instruksi yang diberikan ke komputer.

3. Database

Kumpulan data dan informasi yang diorganisasikan sedemikian rupa sehingga mudah diakses pengguna sistem informasi

4. Telekomunikasi 
Komunikasi yang menghubungkan antara pengguna sistem dengan sistem komputer secara bersama-sama ke dalam suatu jaringan kerja yang efektif.

\section{Manusia}

Personel dari sistem informasi meliputi manajer, analis, programmer, dan operator, serta bertanggung jawab terhadap perawatan sistem.

\subsection{Tipe-Tipe Sistem Informasi}

Sistem informasi berbasis komputer dalam suatu organisasi dibedakan menjadi beberapa tipe aplikasi, yaitu (Muslihudin and Oktafiaanto, 2016):

1. Transaction Processing System (TPS)

Sistem informasi terkomputerisasi yang dikembangkan untuk memproses sejumlah besar data untuk transaksi bisnis rutin.

2. Management Information System (MIS)

Sistem informasi pada level manajemen yang berfungsi untuk membantu perencanaan, pengendalian, dan pengembalian keputusan dengan menyediakan resume rutin dan laporan-laporan tertentu. MIS mengambil data mentah dari TPS dan mengubahnya menjadi kumpulan data yang lebih berarti serta dibutuhkan manajer untuk menjalankan tanggung jawabnya.

3. Decision Support System (DSS)

Sistem informasi pada level manajemen dari suatu organisasi yang mengombinasikan data dan mode analisis canggih atau peralatan data analisis untuk mendukung pengambilan keputusan semi terstruktur maupun tidak terstruktur.

4. Expert Support System (ESS)

Merupakan representasi pengetahuan yang menggambarkan cara seorang ahli dalam mendeteksi suatu masalah. ES lebih berpusat pada bagaima pengodean dan memanipulasi pengetahuan dari informasi (misalnya aturan if...then).

\subsection{Metode Pengembangan Sistem Development Life Cycle/SDLC)}

(System

Sistem yang sedang berjalan atau sedang digunakan oleh organisasi atau perusahaan akan terus dikembangkan untuk memperbaiki kekurangankekurangan pada sistem tersebut (Mulyani, 2017). Metode adalah tahap-tahap atau aturan untuk melakukan sesuatu (Mulyani, 2016b). McLeod dan Schell (dalam Mulyani, 2016) mengatakan metode adalah cara untuk melakukan sesuatu.

Metode pengembangan perangkat lunak atau disebut juga System Development Life Cycle (SDLC) adalah proses yang digunakan oleh analis sistem untuk mengembangkan sistem informasi, mulai dari penentuan kebutuhan, perancangan, validasi, sampai pelatihan dan penyerahan kepada konsumen (Zaliluddin and Rohmat, 2018).

SDLC merupakan alur kerja baku yang biasa dipakai oleh perusahaan-perusahaan vendor software dalam mengembangkan software aplikasi produksinya (Zaliluddin and Rohmat, 2018). SDLC ini tidak hanya penting untuk proses produksi software saja, namun terlebih juga sangat penting untuk proses maintenance software itu sendiri, karena tanpa pengarsipan data-data development suatu software, maka akan sangat menyulitkan perusahaan dalam maintenance software tersebut di kemudian hari (Zaliluddin and Rohmat, 2018).

SDLC identik dengan teknik pengembangan sistem waterfall, karena tahapannya menurun dari atas ke bawah. Berikut tahapan dari SDLC versi McLeod (dalam (Ayu and Permatasari, 2018):

1. Perencanaan (Planning)

2. Analisis (Analysis)

3. Desain (Design)

4. Implementasi (Implementation)

5. Penggunaan (Use)

Tahapan pengembangan metode SDLC menurut McLeod dalam (Ayu and Permatasari, 2018) terlihat pada Gambar 2.

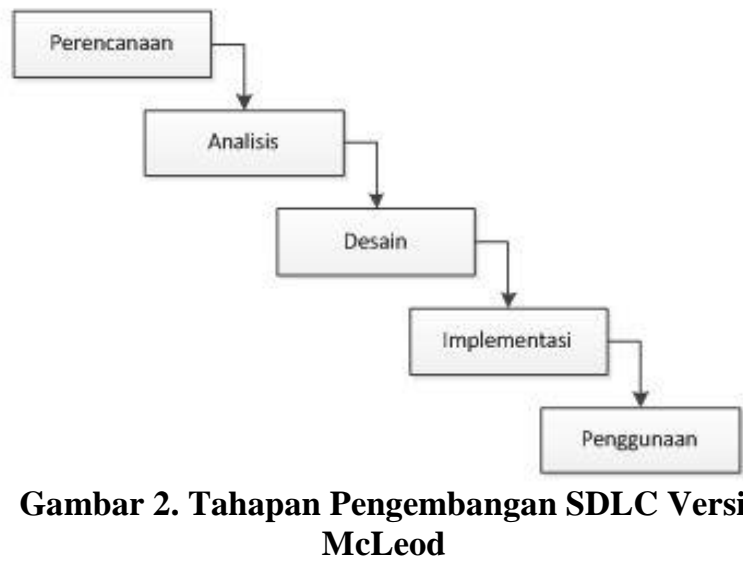

\section{Perencanaan (Planning)}

Pembuatan sebuah sistem informasi dapat dimulai dengan melihat dan mencari apa yang dibutuhkan oleh sistem kemudian kebutuhan sistem tersebut akan diterapkan ke dalam sistem informasi yang dibuat (Susanti, 2016).

2. Analisis (Analysis)

Merupakan proses pengumpulan kebutuhan sistem informasi yang mencakup ruang lingkup informasi, fungsi-fungsi yang dibutuhkan, kemampuan kinerja yang ingin dihasilkan dan perancangan antarmuka pemakai sistem informasi tersebut (Susanti, 2016).

Tahapan analisis sistem dimulai karena adanya permintaan terhadap sistem baru. Permintaan dapat datang dari seorang manajer di luar departemen sistem informasi atau dari pihak eksekutif yang melihat adanya masalah atau menemukan adanya peluang baru. Namun, adakalanya inisiatif pengembangan sistem baru berasal dari bagian yang 
bertanggung jawab terhadap pengembangan sistem informasi, yang bermaksud mengembangkan sistem yang sudah ada atau menangani masalah-masalah yang belum tertangani.

Tujuan utama analisis sistem adalah untuk menentukan hal-hal detail tentang yang akan dikerjakan oleh sistem yang diusulkan (dan bukan bagaimana caranya). Analisis sistem mencakup studi kelayakan dan analisis kebutuhan (Mulyani, 2017).

1) Studi Kelayakan

Studi kelayakan digunakan untuk menentukan kemungkinan keberhasilan solusi yang diusulkan. Tahapan ini berguna untuk memastikan bahwa solusi yang diusulkan tersebut benar-benar dapat dicapai dengan sumber daya dan dengan memperhatikan kendala yang terdapat pada perusahaan dan dampak terhadap lingkungan sekeliling.

Di dalam tahapan ini, analisis sistem melaksanakan penyelidikan awal terhadap masalah dan peluang bisnis yang disajikan dalam usulan proyek. Pengembangan sistem tugas-tugas yang tercakup dalam studi kelayakan meliputi pembentukan sasaran sistem baru secara keseluruhan, pengidentifikasian para pemakai sistem, dan pembentukan lingkup sistem (Mulyani, 2017).

2) Analisis Kebutuhan

Analisis kebutuhan dilakukan untuk menghasilkan spesifikasi kebutuhan (disebut juga spesifikasi fungsional). Spesifikasi kebutuhan adalah spesifikasi yang rinci tentang hal-hal yang dilakukan sistem ketika diimplementasikan. Spesifikasi ini sekaligus dipakai untuk membuat kesepakatan antara pengembang sistem, dan pemakai yang kelak menggunakan sistem, manajemen dan mitra kerja yang lain (misalnya auditor internal).

Ada langkah-langkah yang harus dilakukan untuk proses analisis kebutuhan seperti wawancara, riset terhadap sistem sekarang, observasi lapangan, kuis, pengamatan terhadap sistem serupa, dan prototype (Mulyani, 2017).

3. Desain (Design)

Perancangan sistem informasi merupakan proses bertahap yang memfokuskan pada empat bagian penting, yaitu: Struktur data, arsitektur sistem informasi, detail prosedur, dan karakteristik antar muka pemakai (Susanti, 2016).

Perancangan sistem dibagi menjadi dua sub tahapan, yakni perancangan konseptual, dan perancangan fisik. Target akhir dari tahapan ini adalah menghasilkan rancangan yang memenuhi kebutuhan yang ditentukan selama tahapan analisis sistem. Hasil akhirnya berupa spesifikasi rancangan yang sangat rinci sehingga mudah diwujudkan pada saat pemrograman (Mulyani, 2017).

1) Perancangan konseptual
Perancangan konseptual sering kali disebut perancangan logis. Pada perancangan ini, kebutuhan pemakai dan pemecahan masalah yang teridentifikasi selama tahapan analis sistem mulai dibuat untuk diimplementasikan.

Ada tiga langkah penting yang dilakukan dalam perancangan konseptual, yaitu evaluasi alternatif rancangan, penyiapan spesifikasi rancangan, dan penyiapan laporan rancangan sistem secara konseptual. Evaluasi alternatif rancangan digunakan menentukan alternatifalternatif rancangan yang bisa digunakan dalam sistem.

Pada perancangan konseptual, spesifikasi rancangan mencakup beberapa elemen seperti keluaran yang merupakan rancangan laporan mencakup frekuensi laporan (harian, mingguan, dan sebagainya), isi laporan, bentuk laporan, dan laporan cukup ditampilkan pada layar atau perlu dicetak, penyimpanan data yang dalam hal ini, semua data yang diperlukan untuk membentuk laporan ditentukan lebih detail, termasuk ukuran data (misalnya, nama barang maksimal terdiri atas 25 karakter) letaknya dalam berkas, masukan yang merupakan Rancangan masukan meliputi data yang perlu dimasukkan ke dalam sistem, dan prosedur pemrosesan serta operasi di mana rancangan ini menjelaskan bagaimana data masukan diproses dan disimpan dalam rangka untuk menghasilkan laporan (Mulyani, 2017).

2) Perancangan fisik

Pada perancangan fisik, rancangan yang bersifat konseptual diterjemahkan dalam bentuk fisik sehingga terbentuk spesifikasi yang lengkap tentang modul-modul sistem dan antarmuka antar modul, serta rancangan basis data secara fisik.

Ada beberapa hasil akhir setelah perancangan fisik berakhir, pertama adalah rancangan keluaran yang berupa bentuk laporan dan rancangan dokumen, kemudian rancangan masukan yang berupa rancangan layar untuk pemasukan data, rancangan antarmuka pemakai dan sistem yang berupa rancangan interaksi antara pemakai dan sistem (menu, ikon, dan lain-lain), rancangan platform yang berupa rancangan yang menentukan perangkat keras dan perangkat lunak yang digunakan, rancangan basis data yang berupa rancangan-rancangan berkas dalam basis data, termasuk penentuan kapasitas masingmasing, rancangan modul yang berupa rancangan modul atau program yang dilengkapi dengan algoritma (cara modul atau program kerja bekerja), rancangan kontrol yang berupa rancangan kontrol-kontrol yang digunakan dalam sistem (mencakup hal-hal seperti validasi, otorisasi, dan pengauditan), dokumentasi yang berupa hasil pendokumentasian hingga tahap perancangan sistem, rencana pengujian yang 
berisi rencana yang dipakai untuk menguji sistem dan yang terakhir adalah Rencana konversi, berupa rencana untuk menerapkan sistem baru terhadap sistem lama (Mulyani, 2017).

4. Implementasi (Implementation)

Pada tahap ini mulai dilakukan proses pengodean sistem informasi yang merupakan proses penulisan bahasa program agar sistem informasi tersebut dapat dijalankan oleh mesin (Susanti, 2016). Pada tahap ini terdapat banyak aktivitas yang dilakukan.

1) Pemrograman dan pengujian.

2) Instalasi perangkat keras dan perangkat lunak.

3) Pelatihan kepada pemakai.

4) Konversi.

5) Pembuatan dokumentasi.

Dari beberapa kegiatan di atas, kegiatan penting untuk dibahas lebih lanjut adalah pemrograman, pengujian, konversi, dan pembuatan dokumentasi (Mulyani, 2017).

1) Pemprograman dan pengujian.

Berdasarkan perancangan fisik, mulai dilakukan pemrograman. Setiap program menjalani pengujian secara individual untuk memastikan bahwa program bebas dari kesalahan.

Pengujian seperti ini disebut dengan pengujian unit. Jika terjadi kesalahan, pemakai akan berusaha mencari penyebabnya dan proses untuk melakukan pencarian kesalahan ini dikenal dengan sebutan debugging (Mulyani, 2017). Ada empat tahapan pengujian meliputi pengujian integrasi yang dilakukan setelah semua modul/program melewati pengujian unit untuk melihat efek ketika program saling dikaitkan, pengujian sistem di mana setelah melalui pengujian integrasi, fungsi-fungsi dalam sistem dan juga kinerjanya diuji. Sistem validasi terhadap spesifikasi kebutuhan dengan kondisi dan lingkungan yang menyerupai dengan keadaan dan lingkungan operasional. Pada pengujian ini, kontrol dan prosedur pemulihan sistem (system recovery) juga diuji, pengujian penerimaan yang dilakukan sebelum sistem dioperasikan dengan melibatkan pemakai, pengembangan sistem, personil yang akan memelihara sistem, manajemen, dan auditor internal. Tujuannya adalah untuk meyakinkan bahwa segala kebutuhan telah terpenuhi. Dalam hal ini pemakai akan memberikan persetujuan untuk menerapkan sistem ini sebagai sistem produksi (sistem yang akan dioperasikan oleh pemakai), dan pengujian instalasi jika pengujian penerimaan dilakukan sebelum sistem dipasang ke lingkungan operasional, sistem perlu diuji kembali setelah dipasang pengujian seperti inilah yang disebut pengujian instalasi.

2) Konversi.

Konversi merupakan tahapan yang digunakan untuk mengoperasikan sistem baru dalam rangka menggantikan sistem yang lama. Terdapat beberapa pendekatan yang dilakukan untuk melakukan konversi yaitu konversi paralel, konversi langsung, konversi pilot dan konversi modular atau bertahap.

Konversi paralel di mana sistem baru dan sistem lama sama-sama dijalankan. Setelah melalui masa tertentu, jika sistem baru telah bisa diterima untuk menggantikan sistem lama, maka sistem lama segera dihentikan, konversi langsung yang dilakukan dengan cara menghentikan sistem lama dan menggantikannya dengan sistem baru, konversi pilot yang dilakukan dengan menerapkan sistem baru hanya pada lokasi tertentu yang diperlukan sebagai pelopor. Jika konversi ini dianggap berhasil, maka akan diperluas ke tempat-tempat yang lain, dan konversi modular atau bertahap yang dilakukan dengan menggantikan suatu bagian dari sistem lama dengan sistem baru. Jika terjadi sesuatu, bagian yang baru tersebut akan diganti kembali dengan yang lama. Jika tak terjadi masalah, modul-modul baru akan dipasangkan lagi untuk mengganti modul-modul lama yang lain. Cara seperti ini lebih aman daripada konversi langsung.

3) Pembuatan dokumentasi.

Dokumentasi merupakan hal yang sangat penting dilakukan karena akan menjadi acuan pada tahapan operasi dan pemeliharaan. Pada tahapan implementasi, dokumentasi yang dibuat dapat dibagi menjadi tiga jenis, yaitu dokumentasi pengembangan yang menjabarkan sistem secara lengkap, mencakup deskripsi sistem, bentuk keluaran, bentuk masukan, bentuk basis data, bagan alir program, hasil pengujian, dan bahkan lembar penerimaan pemakai, dokumentasi operasi yang mencakup antara lain jadwal pengoperasian, cara pengoperasian peralatan, faktor-faktor keamanan, dan masa berlakunya suatu berkas, dan dokumentasi pemakai yang berisi petunjuk untuk menggunakan masing-masing program dan juga mencakup materi pelatihan.

5. Penggunaan (Use)

Pada tahap ini akan dilakukan uji kode program yang telah dibuat dengan memfokuskan pada bagian dalam sistem informasi dan tujuannya untuk memastikan bahwa semua pernyataan telah diuji dan memastikan juga bahwa input yang digunakan akan menghasilkan output yang sesuai (Susanti, 2016).

\subsection{Data Flow Diagram (DFD)}

Alat utama untuk merepresentasikan proses komponen sistem dan arus data di antaranya adalah Data Flow Diagram (DFD) (Suharyanto, dkk., 2017). Menurut Loudon dan Loudon (dalam Suharyanto dkk. 2017) Data Flow Diagram menawarkan model grafis logis dari arus informasi, partisi sistem menjadi modul yang menunjukkan tingkat detail yang dapat diatur. Ini secara 
ketat menentukan proses atau transformasi yang terjadi di dalam setiap modul dan antarmuka yang ada di antara keduanya.

Walaupun namanya menunjukkan penekanan pada data, kenyataannya tidak demikian. Penekanan justru diberikan pada proses. Kata data" di sana berarti data yang mengalir. Dengan kata lain, diagram di atas sebenarnya menunjukkan aliran proses. Diagram ini cocok menggambarkan proses untuk di presentasi kepada manajemen/pemilik. karena alat diagram alir data ini hanya menggunakan 4 macam simbol untuk menyatakan aliran proses seluruh sistem (Bagir and Putro, 2018).

Setiap proses yang ada di DFD harus memiliki spesifikasi proses, untuk memudahkan pembaca dalam memahami DFD (Azwir and Patriani, 2017).

Nama proses pada DFD harus menunjukkan suatu pekerjaan atau suatu proses (perpaduan antara kata kerja dengan objek), contohnya membuat purchase order, menghitung persediaan gudang, mengirim email (Azwir and Patriani, 2017). Pada suatu proses harus ada entitas masuk dan entitas keluar yang berhubungan dengan proses, namun pada proses DFD tidak boleh ada nama proses yang sama (Azwir and Patriani, 2017).

\section{PEMBAHASAN}

Berdasarkan hasil perancangan sistem informasi logistik dan pergudangan yang dihasilkan adalah mempermudah input data dan pengolahan data di pergudangan YDBBC. Dengan tahapan awal perencanaan, analisis sistem, perancangan sistem, implementasi sistem.

\subsection{Perencanaan}

Pada tahap ini dilakukan perencanaan pembangunan sistem informasi logistik dan pergudangan yang diharapkan dapat membantu YDBBC dalam proses pengelolaan gudang yang saat ini proses yang berjalan di gudang masih secara manual. Setelah sistem informasi logistik dan pergudangan di gudang YDBBC diterapkan, pengelolaan informasi menjadi lebih cepat dan terdokumentasi dengan baik.

\subsection{Analisis Sistem}

Pada tahap analisis sistem, dilakukan analisis terhadap sistem saat ini (yang diterapkan di gudang YDBBC) dan kemudian dari sistem yang ada tersebut dilakukan pembuatan sistem usulan yang dijadikan dasar dalam pembuatan sistem informasi logistik dan pergudangan. Gambar 3 menunjukkan sistem pengelolaan data gudang yang dilakukan secara manual.

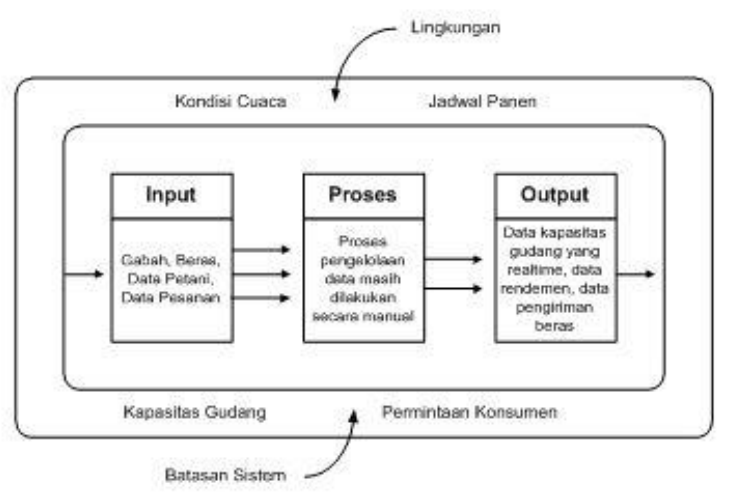

Gambar 3. Sistem Logistik dan Pergudangan Awal

Setelah dilakukan analisis terhadap sistem yang saat ini berjalan di gudang YDBBC, selanjutnya akan disusun sistem usulan pengelolaan data menggunakan sistem informasi logistik dan pergudangan sehingga dapat mempermudah proses pengelolaan data yang ada. Gambar 4 menunjukkan sistem pengelolaan data gudang usulan.

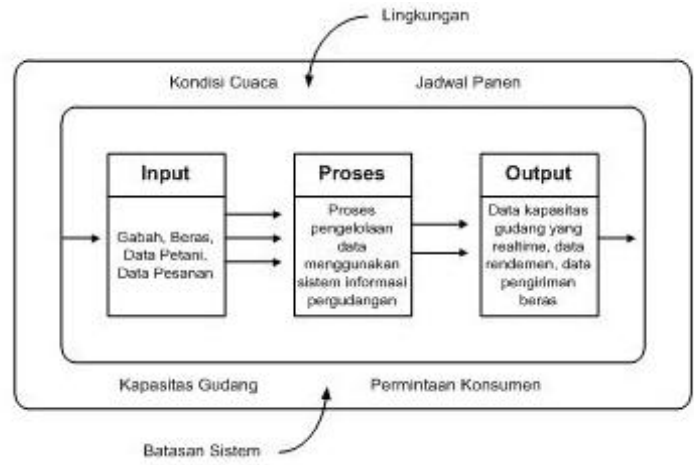

Gambar 4. Sistem Logistik dan Pergudangan Usulan

\subsection{Perancangan Sistem}

Pada tahap perencanaan sistem, disusun sistem manajemen basis data dari sistem informasi logistik dan pergudangan yang dikembangkan. Di bawah ini akan dijelaskan rincian perancangan aliran data, basis data, dan basis model dari sistem informasi tersebut.

1. Context Diagram (CD)

Gambar 5 di bawah ini adalah diagram konteks dari sistem yang dikembangkan. 


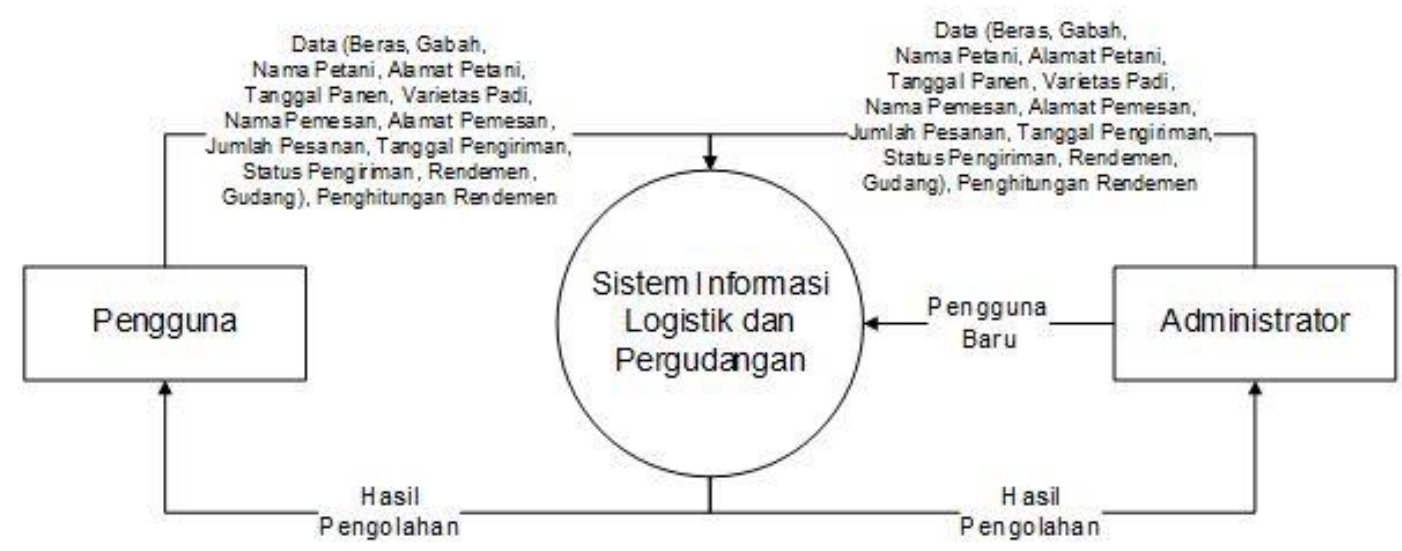

Gambar 5. Context Diagram Sistem Informasi Logistik dan Pergudangan

2. Diagram Dekomposisi

Gambar 6 adalah diagram dekomposisi dari sistem yang dikembangkan.

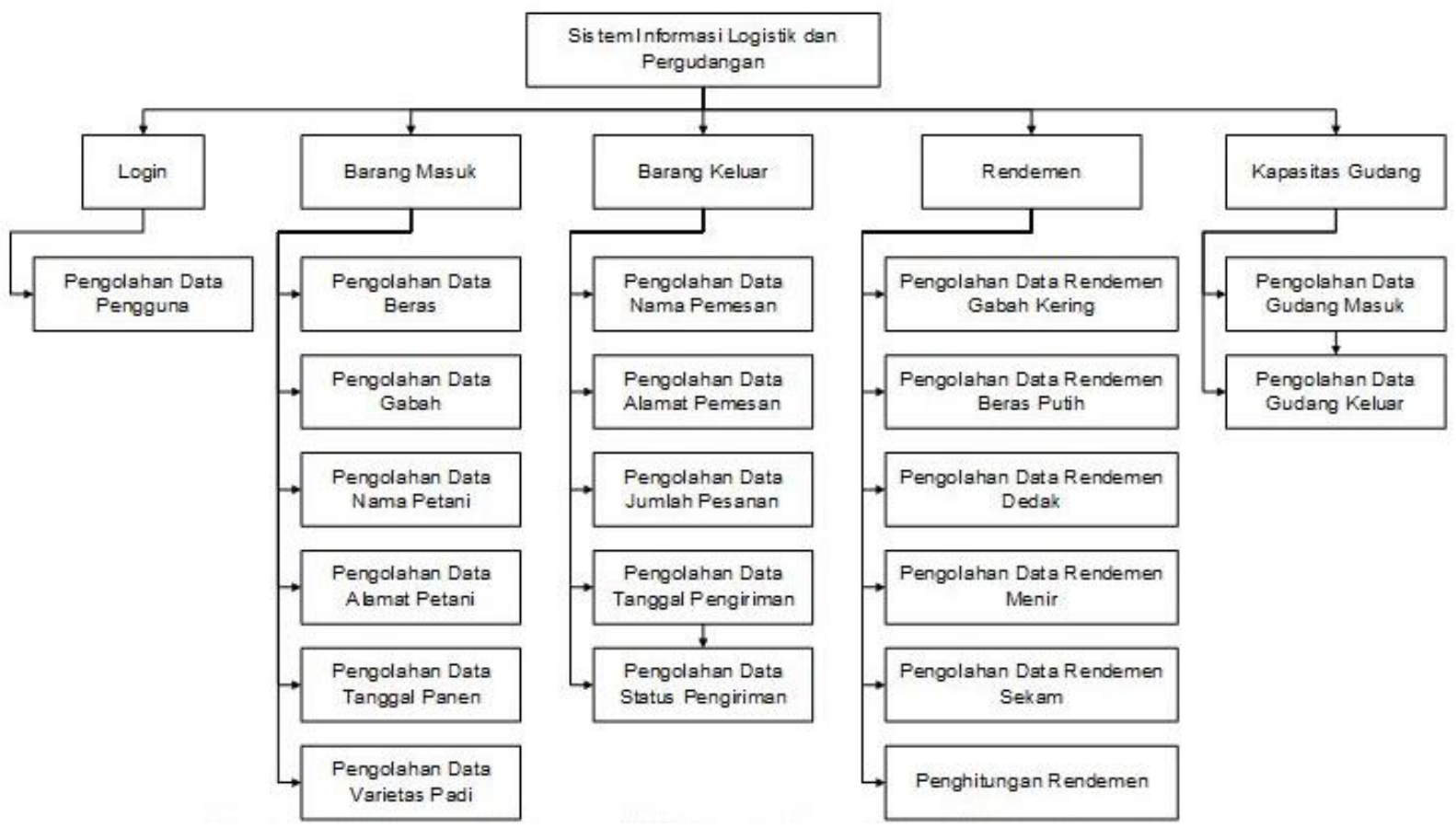

Gambar 6. Diagram Dekomposisi Sistem Informasi Logistik dan Pergudangan

3. Diagram Sistem

Gambar 7 adalah diagram sistem dari sistem yang dikembangkan. 


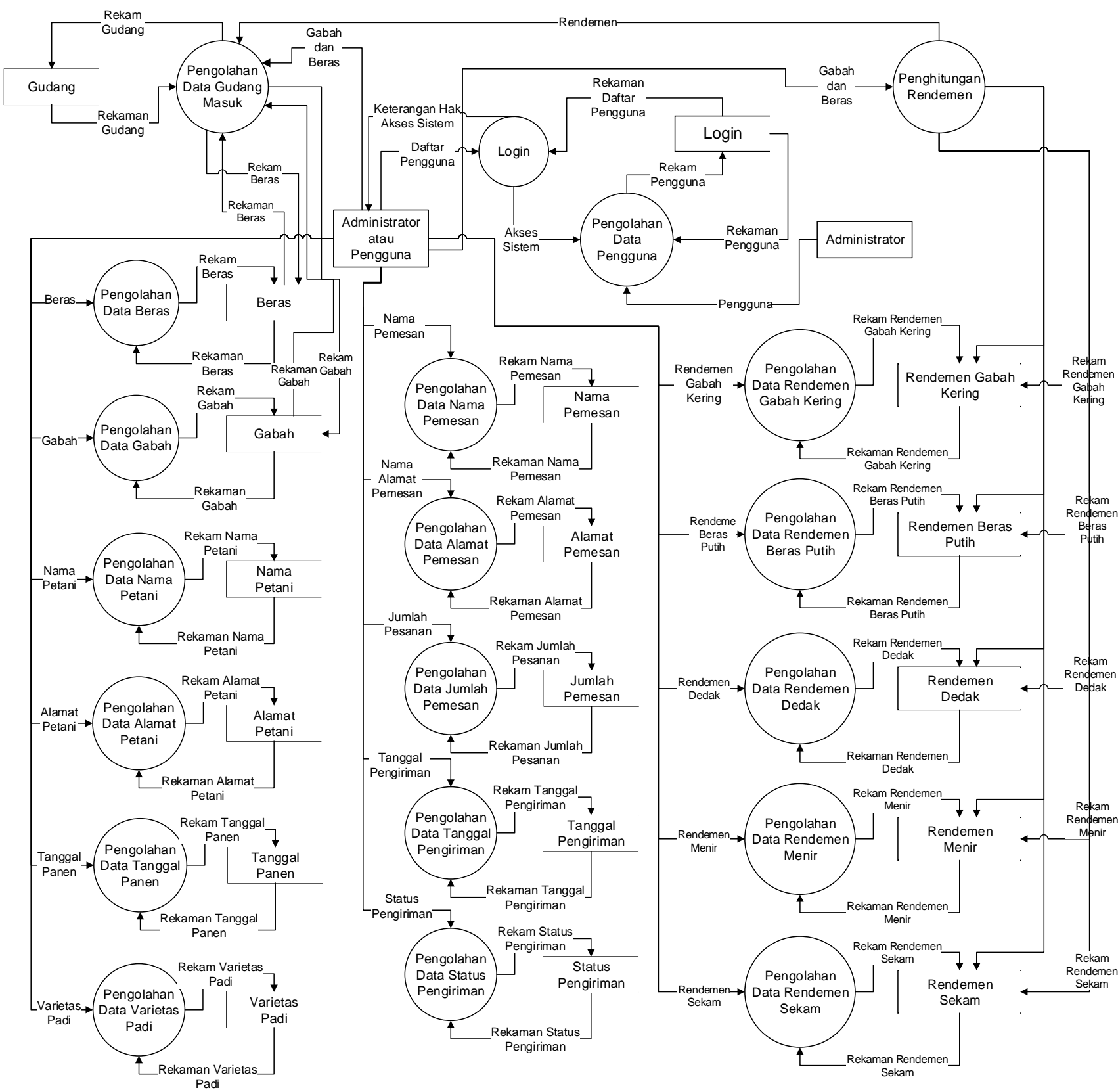

Gambar 7. Diagram Dekomposisi Sistem Informasi Logistik dan Pergudangan

\subsection{Implementasi Sistem}

Dari hasil perancangan sistem informasi logistik dan pergudangan pada bagian sebelumnya, akan diimplementasikan dengan menggunakan bahasa pemrograman C Sharp (C\#) dengan database menggunakan SQL Server. Berikut rincian dan penjelasan dari implementasi sistem yang dikembangkan:

\section{Halaman Login Pengguna}

Halaman login pengguna, dimana administrator atau pengguna harus memasukkan username dan password agar dapat mengakses aplikasi. Halaman log in pengguna dapat dilihat pada gambar 8 .

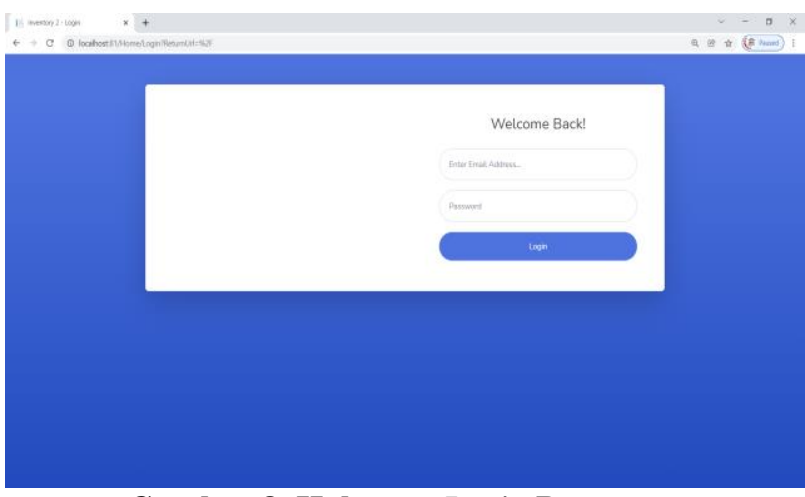

Gambar 8. Halaman Login Pengguna 


\section{Halaman Stock In}

Pada halaman ini berisikan menu-menu yang berkaitan dengan pengelolaan barang masuk ke gudang. Halaman stock in dapat dilihat pada gambar 9 .

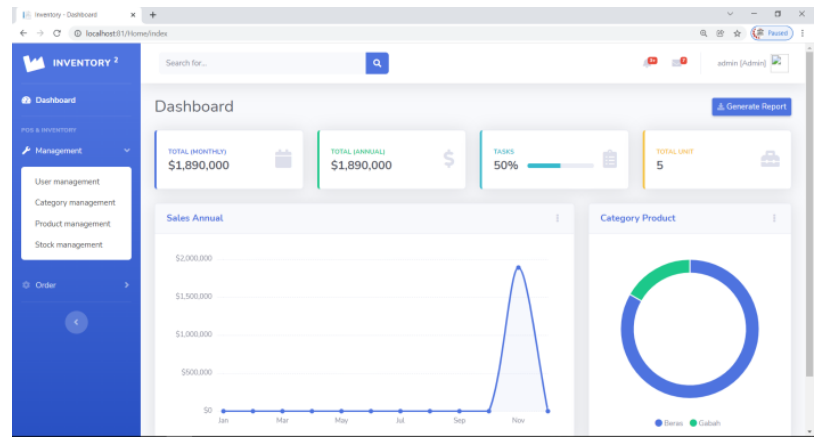

Gambar 9. Halaman Stock In

\section{Halaman Stock Out}

Pada halaman ini berisikan menu-menu yang berkaitan dengan pengelolaan barang keluar dari gudang. Halaman stock out dapat dilihat pada gambar 10 .

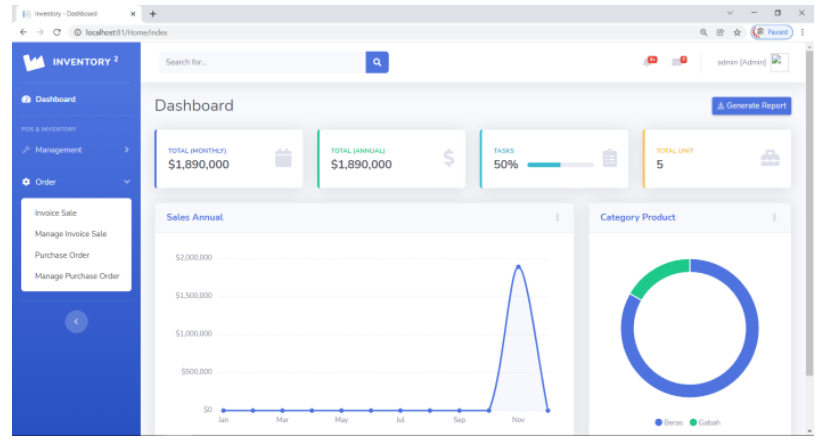

Gambar 10. Halaman Stock Out

\section{Halaman User Management}

Halaman ini memiliki fungsi menambah dan mengurangi daftar pengguna yang diberi akses masuk ke aplikasi ini. Halaman user management dapat dilihat pada gambar 11 .

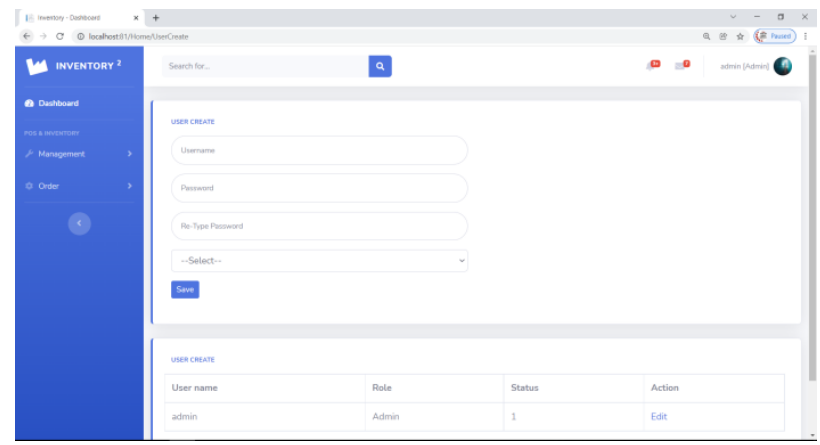

Gambar 11. Halaman User Management

\section{Halaman Product Management}

Halaman ini memiliki fungsi menambah dan mengurangi jenis beras yang akan disimpan di gudang. Halaman product management dapat dilihat pada gambar 12 .

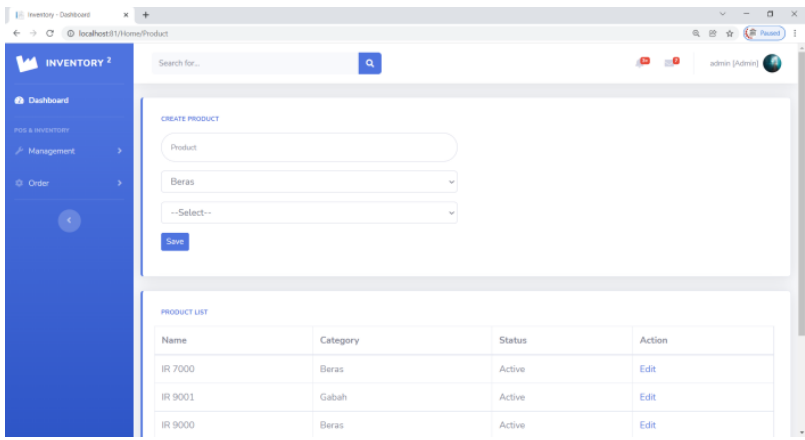

Gambar 12. Halaman Product Management

6. Halaman Stock Management

Halaman ini memiliki fungsi real time dalam menampilkan stok gudang saat ini. Ketika ada barang masuk atau keluar, pada halaman ini otomatis akan menampilkan stok beras terkini yang ada di dalam gudang. Halaman stock management dapat dilihat pada gambar 13 .

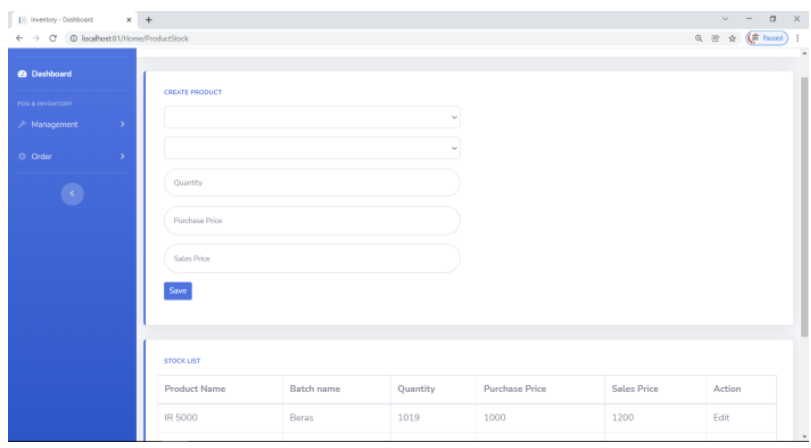

Gambar 13. Halaman Stock Management

\section{Halaman Invoice Sale}

Halaman ini memiliki fungsi untuk menambahkan daftar pembeli beras dimana di dalam invoice sale ini pengguna juga dapat menambahkan detail pesanan dari pembeli. Halaman invoice sale dapat dilihat pada gambar 14.

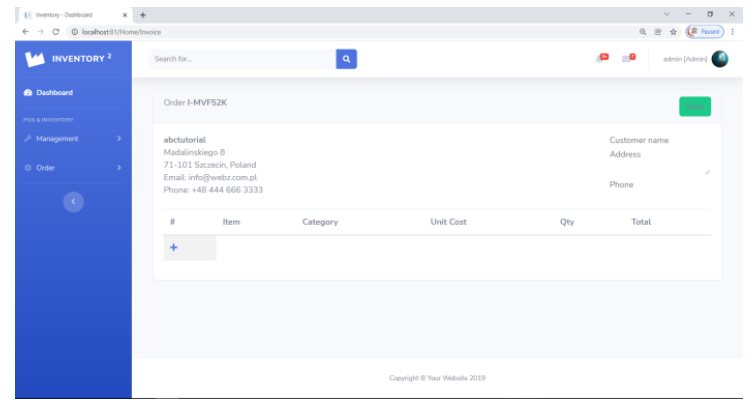

Gambar 14. Halaman Invoice Sale 


\section{Halaman Manage Invoice Sale}

Halaman ini memiliki fungsi untuk menampilkan daftar pembeli beras lengkap dengan biodata pembeli. Pada halaman ini pengguna dapat mengubah daftar pembeli dan biodata pembeli. Halaman manage invoice sale dapat dilihat pada gambar 15 .

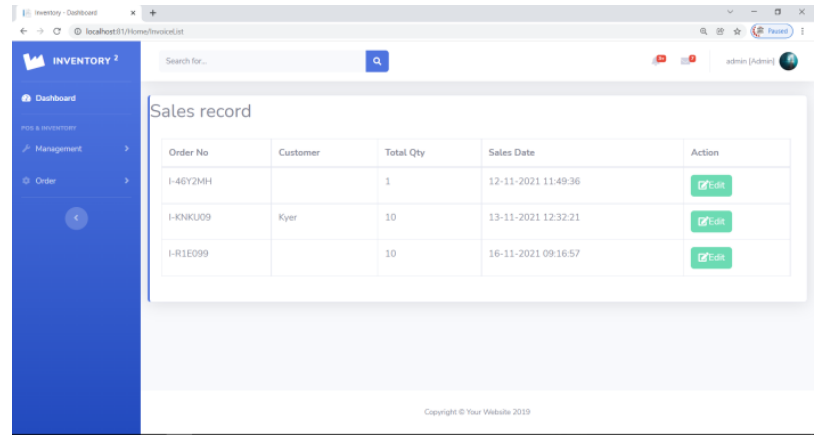

Gambar 15. Halaman Manage Invoice Sale

\section{Halaman Purchase Order}

Halaman ini memiliki fungsi untuk menampilkan data pemasok beras ke gudang yang dilengkapi dengan detail dari pesanan. Halaman purchase order dapat dilihat pada gambar 16.

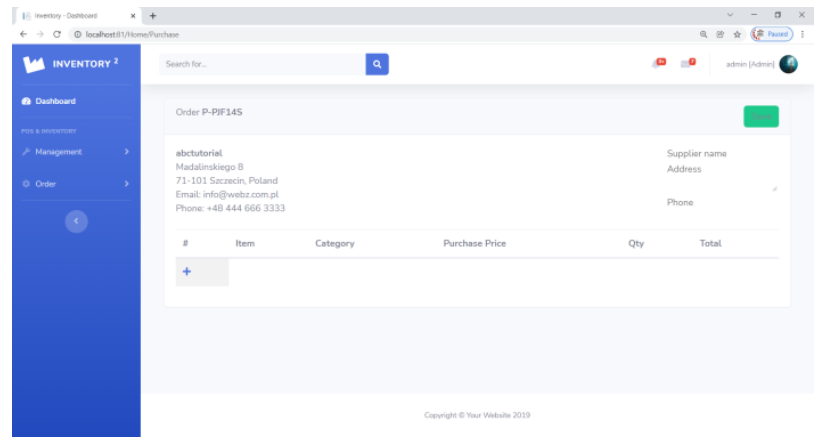

Gambar 16. Halaman Purchase Order

\section{Halaman Manage Purchase Order}

Halaman ini memiliki fungsi menampilkan daftar pemasok beras yang dilengkapi dengan biodata dari pemasok. Halaman manage purchase order dapat dilihat pada gambar 17 .

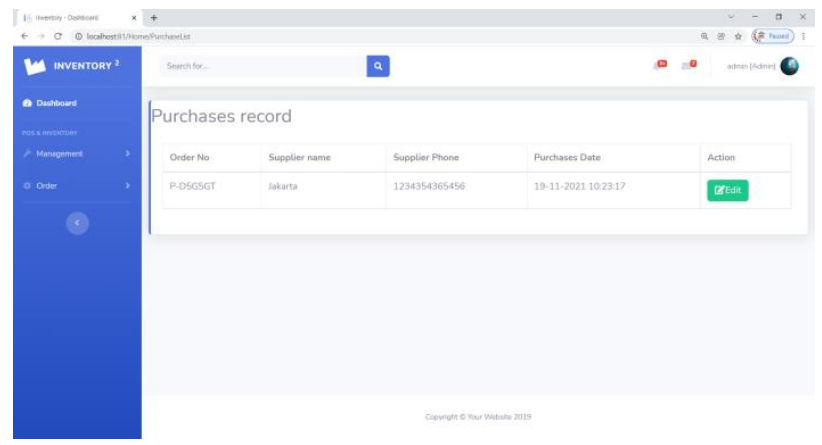

Gambar 17. Halaman Manage Purchase Order

\section{Halaman Dashboard}

Pada halaman ini ditampilkan kondisi terkini dari gudang seperti pemasukan bulanan, pemasukan total, progres tugas, daftar pesanan, serta grafik pendapatan dan sumber pendapatan. Halaman dashboard dapat dilihat pada gambar 18.

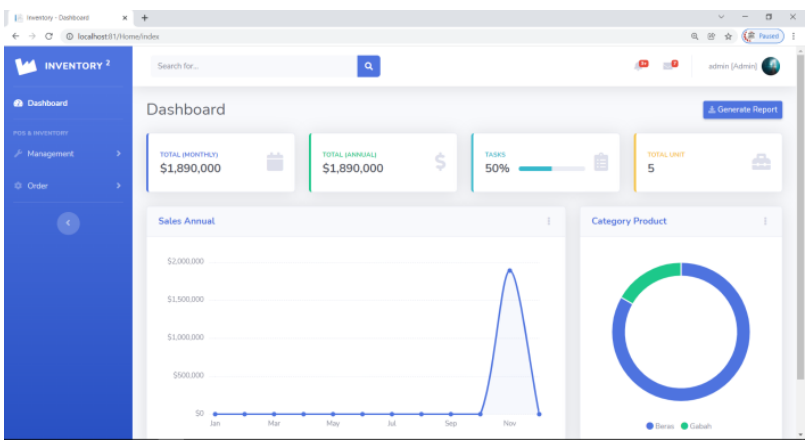

Gambar 18. Halaman Dashboard

\section{KESIMPULAN}

Sistem informasi logistik dan pergudangan yang dikembangkan mampu berjalan dengan baik di gudang YDBBC. Penerapan sistem informasi ini terbukti dapat memudahkan karyawan dalam proses pengelolaan data gudang mulai dari beras masuk ke gudang, pengelolaan stok gudang, sampai pengelolaan data pemesan atau konsumen beras dari gudang.

Adanya fitur dalam sistem informasi seperti stock in, stock out, user management, product management, invoice, purchase, dan dashboard sangat memudahkan pengelola gudang dalam proses pengelolaan administrasi maupun perekaman data gudang serta data yang di input akan langsung tersimpan secara otomatis sehingga meminimalisasi potensi data hilang.. Sistem informasi ini juga dapat menampilkan data real time kapasitas gudang saat ini sehingga pengelola gudang dapat mengetahui berapa kapasitas gudang saat ini.

\section{SARAN}

Pengembangan lebih lanjut dari penelitian ini masih terbuka lebar. Pengembangan sistem yang lebih luas dari sistem yang sudah dikembangkan sekarang ini dengan penambahan fungsi dan fitur yang lebih beragam akan membuat hasil dari penelitian yang selanjutnya lebih baik lagi. Pengembangan sistem berbasis online sehingga memudahkan penggunaan aplikasi dan pemantauan secara mobile menjadi peluang pengembangan sistem ke depannya.

\section{DAFTAR PUSTAKA}

Ayu, F. and Permatasari, N. 2018. 'perancangan sistem informasi pengolahan data PKL pada divisi humas PT pegadaian', Jurnal Infra tech, 2(2), pp. 12-26. Available at: http://journal.amikmahaputra.ac.id/index.php/JIT/ar ticle/download/33/25. 
Azwir, H. H. and Patriani, O. 2017. 'Perbaikan Pengelolaan Pergudangan Melalui Penerapan Sistem Informasi Pergudangan di CV. ABB', Jurnal Optimasi Sistem Industri, 16(1), p. 10. doi: 10.25077/josi.v16.n1.p10-24.2017.

Bagir, H. and Putro, B. E. 2018. 'Analisis Perancangan Sistem Informasi Pergudangan di CV. Karya Nugraha', Jurnal Media Teknik dan Sistem Industri, 2(1), p. 30. doi: 10.35194/jmtsi.v2i1.274.

Basar, A. R., Putri, W. L. and Simarmata, C. 2021 'Perancangan Aplikasi Pengolahan Data Logistik Pada Biro Logistik Polda Kepri', Teknik Ibnu Sina, 6(1), pp. 17-28. doi: 10.3652/jt-ibsi.v6i01.257.

Ekawati, R. and Wahyudiharto, E. 2021. Perancangan Strategis Sistem Informasi, CV. Media Sains Indonesia. Available

at: https://books.google.co.id/books?id=vmxCEAAAQ BAJ\&printsec $=$ frontcover \&source $=$ gbs_ge_summa ry_r\&cad $=0 \# \mathrm{v}=$ onepage $\& \mathrm{q} \& \mathrm{f}=$ false (Accessed: 18 November 2021).

Heriyanto, Y. 2018. 'Perancangan Sistem Informasi Rental Mobil Berbasis Web Pada PT APM Rent Car', Intra-Tech, 2(2), pp. 64-77.

Muslihudin, M. and Oktavianto. 2016. Analisis dan Perancangan Sistem Informasi Menggunakan Model Terstruktur dan UML, Andi Offset. Available at:

https://books.google.co.id/books?id=2SU3DgAAQ BAJ\&printsec $=$ frontcover \&source $=g b s \_g e \_s u m m a$ ry_r\&cad $=0 \# \mathrm{v}=$ onepage $\& \mathrm{q} \& \mathrm{f}=$ false $($ Accessed: 18 November 2021).

Mulyani, S. 2016a. Analisis dan Perancangan Sistem Informasi Manajemen Keuangan Daerah: Notasi, Abdi Sistematika. Available at: https://books.google.co.id/books?id=_7nPDgAAQ BAJ\&printsec $=$ frontcover $\&$ source $=$ gbs_ge_summa ry_r\&cad $=0 \# \mathrm{v}=$ onepage $\& \mathrm{q} \& \mathrm{f}=$ false $($ Accessed: 18 November 2021).

Mulyani, S. 2016b. Sistem Informasi Manajemen Rumah Sakit: Analisis dan Perancangan, Abdi Sistematika. Available

at: https://books.google.co.id/books?id=k7rPDgAAQB $\mathrm{AJ} \&$ printsec $=$ frontcover $\&$ source $=g b s \_g e \_s u m m a r y$ _r\&cad $=0 \# \mathrm{v}=$ onepage $\& \mathrm{q} \& \mathrm{f}=$ false $\quad$ (Accessed: 18 November 2021).

Mulyani, S. 2017. Metode Analisis dan Perancangan Sistem, Abdi Sistematika. Available at: https://books.google.co.id/books?id=SbrPDgAAQB AJ\&printsec $=$ frontcover\&source $=g b s \_g e \_s u m m a r y$ _r\&cad $=0 \# \mathrm{v}=$ onepage $\& \mathrm{q} \& \mathrm{f}=$ false $\quad$ (Accessed: 18 November 2021).

Prasetyo, H. A., Priyambadha, B. and Arwan, A. 2018. 'Pembangunan Aplikasi Sistem Informasi Pergudangan pada Rumah Sakit', Jurnal Pengembangan Teknologi Informasi dan Ilmu Komputer, 2(7), pp. 2789-2800.

Pujiiastuti, L., Poningsih, P. and Sri Wulandika, Solikhun, S. 2020, Buku Tuntunan Praktis
Membangun Sistem Informasi menggunakan PHP5 \& Mysql, Yayasan Kita Menulis. Available at: https://books.google.co.id/books?id=ph3sDwAAQ BAJ\&printsec $=$ frontcover \&source $=$ gbs_ge_summa ry_r\&cad $=0 \# \mathrm{v}=$ onepage $\& \mathrm{q} \& \mathrm{f}=$ false $($ Accessed: 18 November 2021).

Satyagraha, A., Witanti, W. and Ashaury, H. 2020. 'Pembanngunan Sistem Informasi Monitoring Logistik di PT Dirgantara Indonesia', Sainteks, 13, pp. 142-146.

Setiawan, E. B. and Setiyadi, A. 2017. 'Implementasi Supply Chain Management (SCM) Dalam Sistem Informasi Gudang Untuk Meningkatkan', Seminar Nasional Teknologi Informasi dan Multimedia.

Suharyanto, C. E., Chandra, J. E. and Gunawan, F. E. 2017. 'Perancangan Sistem Informasi Penggajian Terintegrasi Berbasis Web (Studi Kasus di Rumah Sakit St. Elisabeth)', Jurnal Nasional Teknologi dan Sistem Informasi, 3(2), pp. 225-232. doi: 10.25077/teknosi.v3i2.2017.225-232.

Sukendar, E. 2018. 'Sistem Informasi Manajemen Logistik dan Pergudangan', Ilmiah Indonesia, 9(1), pp. $1-11$ Available at: http://dx.doi.org/10.1016/j.neuropsychologia.2015. 07.010\%0Ahttp://dx.doi.org/10.1016/j.visres.2014. 07.001\%0Ahttps://doi.org/10.1016/j.humov.2018.0 8.006\%0Ahttp://www.ncbi.nlm.nih.gov/pubmed/24 582474\%0Ahttps://doi.org/10.1016/j.gaitpost.2018. 12.007\%0Ahttps:

Susanti, M. 2016. 'Perancangan Sistem Informasi Akademik Berbasis Web Pada Smk Pasar Minggu Jakarta', Informatika, 3(1), pp. 91-99.

Wadisman, C. 2018. 'Perancangan Aplikasi Pengolahan Data Logistik Pada Kantor Cabang Bri Solok', Information Technology and Computer Science, 151(2), pp. 10-17.

Yanuar, A., Rahmatuloh, M. and Mutaqien, I. 2021. 'Metode FSN Analysis Dan Implementasinya Pada Desain Sistem Informasi Pergudangan', Ilmiah Media SISFO, 15(1), pp. 60-75.

Zaliluddin, D. and Rohmat, R. 2018. 'Perancangan Sistem Informasi Penjualan Berbasis Web (Studi Kasus Pada Newbiestore)', Infotech Journal, 4(1), p. 236615.

\section{UCAPAN TERIMA KASIH}

Terima kasih kami ucapkan kepada Kementerian Pendidikan, Kebudayaan, Riset, dan Teknologi yang telah memberikan dana hibah Penelitian Dasar Tahun Tunggal serta Yayasan Dharma Bhakti Berau Coal yang telah membantu kami dalam proses penelitian ini mulai dari proses observasi lapangan, pengambilan data, pengujian aplikasi. 